\title{
KERAGAMAN KARAKTER MORFO-AGRONOMI DAN KEANEKARAGAMAN GALUR- GALUR CABAI BESAR (Capsicum annuum L.)
}

\section{VARIABILITY OF MORPHO-AGRONOMIC CHARACTERS AND DIVERSITY OF CHILI PEPPER (Capsicum annuum L.) LINES}

\author{
Nur Indah Agustina ${ }^{1}$, Budi Waluyo ${ }^{2^{*}}$ \\ ${ }^{1}$ Program Studi Agroekoteknologi Fakultas Pertanian Universitas Brawijaya \\ ${ }^{2} J u r u s a n$ Budidaya Pertanian Fakultas Pertanian Universitas Brawijaya \\ Korespondensi : budiwaluyo@ub.ac.id
}

Diterima 15 September 2017 / Disetujui 27 Desember 2017

\begin{abstract}
ABSTRAK
Tujuan penelitian ini untuk mempelajari keragaman karakter morfo-agronomi, jarak genetik dan keanekaragaman 39 galur cabai besar. Penelitian ini dilaksanakan pada bulan Januari sampai Juni 2017 di Kebun Percobaan Agro Techno Park Universitas Brawijaya yang berlokasi di Desa Jatikerto, Kecamatan Kromengan, Kabupaten Malang. Penelitian menggunakan rancangan acak kelompok (RAK) dengan perlakuan 39 genotip cabai besar diulang 2 kali. Pengamatan dilakukan terhadap karakter agronomi. Keragaman dipelajari berdasarkan principal component analysis (PCA) dengan pendekatan koefisien korelasi Pearson. Pengelompokkan galur berdasarkan agglomerative hierarchical clustering (AHC) dengan similaritas koefisien korelasi Pearson dan metode aglomerasi unweighted pair-group average. Indeks Shanon $\left(H^{\prime}\right)$ dan indeks Simpson (D) digunakan untuk mengetahui keanekaragaman genetik. Keragaman karakter agronomi 39 galur cabai berdasarkan principal component analysis (PCA) terbagi menjadi 9 komponen utama (principal component, PC) dengan nilai keragaman kumulatif $82,59 \%$. Galur-galur cabai besar terbagi menjadi empat kelompok utama pada koefisien 91\%-100\%. Keeratan jarak genetik berdasarkan 24 karakter kualitatif dan 18 karakter kuantitatif berdasarkan Mantel test menunjukkan nilai koefisien korelasi yang positif nyata $(r=0,173$ dan nilai $P<0,0001$ ). Indeks keanekaragaman genetik kelompok galur-galur cabai termasuk kategori indek Shannon 1-3 menunjukkan tingkat sedang dan indeks Simpson 0,39 menunjukkan tingkat rendah. Presentase proporsi kelimpahan menunjukkan kelompok $A$ memiliki kelimpahan tertinggi dan kelompok D memiliki kelimpahan terendah.
\end{abstract}

Kata kunci: cabai besar, jarak genetik, keanekaragaman, keragaman

\begin{abstract}
The objective of this research was to study the variability of morpho-agronomic characters, genetic distance, and genetic diversity of 39 chili pepper lines. The experiment was conducted from January until June 2017, in Agro Techno Park of Universitas Brawijaya, at Jatikerto, Malang Regency. This research was conducted by using randomized block design (RBD) with treatment of 39 chili pepper genotypes repeated two times. Observation was made on agronomic characters. The variability was analyzed by principal components analysis (PCA)
\end{abstract}


with the approach of the Pearson correlation. Agglomerative hierarchical clustering (AHC) with the Pearson correlation coefficient of similarity and agglomeration method unweighted pairgroup average was performed for lines grouping. Genetic diversity was obtained using Shannon index $\left(\mathrm{H}^{\prime}\right)$ and Simpson index (D). The agronomic characters variability of chili pepper lines based on principal component analysis (PCA) was divided into 9 principal components with cumulative variability value $82,59 \%$. Genetic distance was divided into four main groups at coefficient of $91 \%-100 \%$. Mantel test of genetic distance based on 24 qualitative and 18 quantitative characters showed a significant positive correlation coefficient $(r=0,173$ and $P$ $<0,0001)$. Diversity index based Shannon index $\left(H^{\prime}\right)$ included category 1-3 showed that the level of diversity was medium, and based on Simpson index 0,39 showed a low level diversity. The percentage proportion of the abundance in four groups showed a variation. Group A had the highest abundance and group $D$ was the lowest.

Key words : chili pepper, diversity, genetic distance, variability

\section{PENDAHULUAN}

Cabai besar (Capsicum annuum L.) adalah salah satu tanaman rempah-rempah yang paling penting di seluruh dunia, dengan produksi global 23,9 juta ton untuk cabai segar dan 2,5 juta ton cabai kering dan panen 3,5 juta ton (Deka et al., 2016). Cabai besar mempunyai kontribusi 9,02\% terhadap produksi sayur nasional, dan produksi cabai Indonesia selama tahun 2009 - 2014 berjumlah 0,78;0,80;0,88; 0,95; 1,$01 ;$ dan $1,07 \mathrm{t}$ dengan produktivitas berkisar antara 6,72 sampai dengan 8,35 $\mathrm{t}$ ha $^{-1}$ (Direktorat Jenderal Hortikultura, 2014). Peningkatan produksi yang linier terhadap produktivitas menunjukkan belum dioptimalkannya potensi genetik cabai. Produktivitas cabai tersebut masih tergolong rendah apabila dibandingkan dengan potensi hasil $22 \mathrm{t} \mathrm{ha}^{-1}$ (Syukur et al., 2014). Menurut Zhigila et al. (2014) nama yang paling umum terdiri dari Bell Pepper, Cayenne Pepper, Jalapeño Pepper, Serrano Pepper, Chiltepin Pepper dan Christmas Pepper. Bentuk dan ukuran buah yang mirip walau mempunyai spesies yang berbeda sering menjadi informasi di dalam pemanfaatan cabai sebagai cabai besar
(Krishnamurthy et al., 2012; Moses and Umaharan, 2012; Shiva et al., 2014)

Perlu dilakukan studi keragaman genetik terhadap koleksi genotip cabai besar. Keragaman berguna untuk mengetahui pola pengelompokan populasi genotipe yang dimiliki dan untuk mengetahui karakter penciri setiap kelompok genotipe yang terbentuk (Zhigila et al., 2014) sehingga dapat digunakan dalam kegiatan seleksi tetua untuk perakitan varietas unggul baru. Menurut Sriyadi (2015) keragaman genetik dalam satu populasi dapat digunakan sebagai pemandu memilih tetua dalam persilangan buatan untuk membentuk populasi hibrid sebagai materi seleksi.

Evaluasi jarak genetik dapat dijadikan dasar dalam pemilihan tetua potensial dalam program pemuliaan tanaman (Lahbib et al., 2013). Informasi jarak genetik dan hubungan kekerabatan sangat diperlukan di dalam pembentukan populasi dasar untuk merakit varietas unggul (Geleta et al., 2004; Sitaresmi et al., 2010). Semakin jauh jarak genetik antar tetua maka peluang mendapatkan populasi baru dengan variabilitas genetik yang luas semakin besar sehingga memperbesar peluang untuk dilakukan seleksi genotip unggul. 
Keanekaragaman genetik adalah suatu tingkatan yang merujuk pada jumlah total variasi genetik dalam keseluruhan spesies (Lowe, Harris dan Ashton, 2006; Hughes et al., 2008; Maurer and McGill, 2011). Menurut Setiawati (2010) pola keeratan hubungan antara genotip-genotip serta keanekaragaman genetik yang tinggi dapat digunakan sebagi acuan pemilihan tetua persilangan merakit varietas baru dan memperkaya keragaman genetik. Julisaniah et al. (2008) menambahkan bahwa semakin tinggi keanekaragaman genetiknya maka semakin besar kemungkinan diperoleh genotipe unggul.

\section{BAHAN DAN METODE}

Penelitian dilaksanakan di Kebun Percobaan Agrotecnopark Universitas Brawijaya Desa Jatikerto, Kecamatan Kromengan, Kabupaten Malang pada Januari-Juni 2017. Alat yang digunakan dalam penelitian ini yaitu jangka sorong, timbangan analitik, tali, sprayer, ajir bambu, meteran ukur, cangkul, pelubang mulsa, gunting, alat tulis, dan kamera digital.

Bahan tanam yang digunakan dalam penelitian yaitu 39 genotip cabai (Capsicum annuum. L), yaitu (CB/08-PT1146, CB/09BW12, CB/10-UK154, CB/08-28, CB/1040BT2, CB/10-09-R0, CB/08-6, CB/08-48, $\mathrm{CB} / 10-17-\mathrm{U}, \mathrm{CB} / 10-12-\mathrm{R} 1, \mathrm{CB} / 08-\mathrm{BTR} 32$, $\mathrm{CB} / 08-36, \mathrm{CB} / 09-\mathrm{BW} 42, \mathrm{CB} / 08-41, \mathrm{CB} / 10$ 38-TJ2, CB/09-BW52, CB/08-ІА3952, $\mathrm{CB} / 10-14-\mathrm{R} 7 / 8$, CB/08-PT1456, CB/09BW32, CB/10-21-T1, CB/08-35, CB/08-18, $\mathrm{CB} / 08-5, \mathrm{CB} / 10-\mathrm{CYM} 2151, \mathrm{CB} / 09-B W 22$, CB/08-19, CB/08-42, CB/10-22-T2, CB/0839-TS, A4-9(U1-9), B6-38(U2-1), B22(U2-7), B6-38(U2-2), B6-38(U2-2B), G7(5), G10(12), G11(7) dan G11(8)). Bahan lain yang digunakan dalam penelitian ini yaitu pupuk kandang $20 \mathrm{t} \mathrm{ha}^{-1}$, pupuk NPK Mutiara (16-16-16) $450 \mathrm{~kg} \mathrm{ha}^{-1}$, polibag, benih, mulsa plastik hitam perak, kertas label, papan label dan pestisida.

Metode yang digunakan ialah Rancangan Acak Kelompok (RAK) yang terdiri dari 39 galur sebagai perlakuan dengan 2 kali ulangan. Karakter agronomi yang diamati terdiri dari karakter kualitatif dan kuantitatif. Karakter kualitatif yang diamati ialah posisi bunga, tepian kelopak bunga, bentuk pangkal buah, bentuk buah ,warna buah matang, posisi buah, tipe pertumbuhan tanaman, bentuk ujung buah, warna hipokotil, bentuk buah, warna buah sebelum matang, warna kepala sari, leher pada pangkal buah, dan warna daun. Karakter kuantitatif yang diamati tinggi tanaman, diameter batang, jumlah lokul buah, panjang buah, diameter buah, tebal daging buah, berat per buah, jumlah biji per buah, umur berbunga, jumlah buah per tanaman, berat buah per tanaman, panjang batang utama, panjang helai daun, lebar helai daun, panjang tangkai buah, lebar kanopi, dan bobot 1.000 biji sesuai dengan Descriptor for Capsicum (Capsicum spp.) dari International Plant Genetic Resources Institute (IPGRI, 1995).

Keragaman maksimun karakter agronomi yang terdiri dari karakter kualitatif dan kuantitatif ditentukan berdasarkan principal component analysis (PCA) dengan tipe korelasi Pearson. Banyaknya komponen utama yang berpengaruh terhadap keragaman total ditentukan berdasarkan eigenvalue $>1$. Karakter yang berkontribusi terhadap keragaman maksimum ditentukan berdasarkan factor loadings $>0,5$ (Wolfoord, 2015). 
Analisis pengelompokkan dan jarak genetik dilakukan dengan melibatkan karakter kualitatif dan kuantitatif yang nyata berkontribusi terhadap keragaman berdasarkan analisis PCA. Pengelompokkan dan jarak genetik dilakukan dengan analisis kluster berdasarkan agglomerative hierarchical clustering berdasar similiritas menggunakan ukuran koefisien korelasi Pearson dan metode aglomerasi unweighted pair-group method average (UPGMA). Keeratan jarak genetik berdasarkan karakter agronomi kualitatif (morfologi) dan karakter agronomi kuantitatif dianalisis menggunakan korelasi dan uji Mantel. Analisis data menggunakan XLSTAT Version 2009.3.02.

Analisis keanekaragaman dilakukan berdasarkan metode indeks Shanon dan indeks Simpson menggunakan spreadsheet diversity calculator (Goepel, 2014). Indeks keanekaragaman Shanon (Magurran, 2004):

$$
H^{\prime}=-\sum_{i=1}^{s} p_{i} \ln p_{i}
$$

Keterangan :

$\mathrm{H}^{\prime}$ : Indexs keanekaragaman Shanon

$p_{i}: n_{i} / N$

$\mathrm{N}$ : Jumlah individu dari seluruh galur

$\mathrm{n}_{\mathrm{i}}$ : Jumlah jenis ke-i dalam sampel total

$s$ : Jumlah galur

In : Logaritma natural

Indeks Dominansi Simpson (D)

$$
D=\sum p_{i}^{2}
$$

Nilai $P_{i}$ diperoleh dengan menggunakan rumus:

$$
p_{i}=\frac{n_{i}}{N}
$$

Keterangan

D : Indeks Simpson

$\mathrm{N}$ : Total individu dari seluruh galur

$\mathrm{n}_{\mathrm{i}}$ : Banyaknya galur pada kelompok ke $-\mathrm{i}$

\section{HASIL DAN PEMBAHASAN}

Hasil evaluasi keragaman berdasarkan analisis komponen utama (PCA) pada 42 karakter agronomi dari 39 genotip cabai besar terdapat 9 komponen yang memiliki nilai eigenvalue > 1 dengan nilai kearagaman kumulatif 82,59\% (Tabel 1).

Komponen utama pertama (PC1) mempunyai eigenvalue 7,42 memberikan kontribusi terhadap keragaman maksimum sebesar 23,94 \%. Karakter yang berkontribusi terhadap PC1 ialah tinggi tanaman, diameter batang, jumlah lokul buah, posisi bunga, tepian kelopak bunga, bentuk pangkal buah, panjang buah, diameter buah, tebal daging buah, berat per buah, jumlah biji per buah, bentuk buah, warna buah matang, posisi buah, tipe pertumbuhan tanaman dan bentuk ujung buah. Komponen utama kedua (PC2) mempunyai eigenvalue 4,36 memberikan kontribusi terhadap keragaman maksimum sebesar 14,07 \%. Karakter yang berkontribusi terhadap PC2 ialah warna hipokotil (2), umur berbunga, jumlah buah per tanaman, berat buah per tanaman, posisi bunga, warna buah matang dan posisi buah. Komponen utama ketiga (PC3) mempunyai eigenvalue 3,73 memberikan kontribusi terhadap keragaman maksimum sebesar 12,03 \%. Karakter yang berkontribusi terhadap PC3 ialah tinggi tanaman, panjang batang utama, panjang helai daun, lebar helai daun dan panjang tangkai buah. Komponen utama keempat (PC4) mempunyai eigenvalue 2,89 memberikan kontribusi terhadap keragaman maksimum sebesar 9,33\%. Karakter yang berkontribusi terhadap PC4 ialah lebar kanopi, tipe pertumbuhan tanaman, bentuk ujung buah, berat buah pertanaman, dan bentuk buah. Komponen 
utama kelima (PC5) mempunyai eigenvalue 1,65 memberikan kontribusi terhadap keragaman maksimum sebesar 5,32\%. Karakter yang berkontribusi terhadap PC5 ialah warna buah sebelum matang. Komponen utama keenam (PC6) mempunyai eigenvalue 1,63 memberikan kontribusi terhadap keragaman maksimum sebesar 5,26\%. Karakter yang berkontribusi terhadap PC6 ialah tepian kelopak bunga dan bobot 1.000 biji.

Tabel 1. Eigenvalue, keragaman, keragaman kumulatif dan factor loading 39 galur cabai berdasarkan 42 karakter agronomi

\begin{tabular}{|c|c|c|c|c|c|c|c|c|c|}
\hline Komponen dan karakter & PC1 & PC2 & PC3 & PC4 & PC5 & PC6 & PC7 & PC8 & PC9 \\
\hline Umur berbunga (hst) & $-0,29$ & $-0,68^{*}$ & 0,22 & $-0,22$ & 0,03 & $-0,02$ & 0,18 & 0,04 & $-0,10$ \\
\hline Umur panen (hst) & $-0,26$ & 0,06 & 0,35 & $-0,30$ & 0,37 & 0,40 & 0,37 & $-0,17$ & $-0,20$ \\
\hline Tinggi tanaman (cm) & $-0,53^{*}$ & $-0,10$ & $0,66^{*}$ & 0,32 & $-0,12$ & 0,02 & 0,00 & 0,09 & 0,09 \\
\hline Panjang batang utama $(\mathrm{cm})$ & $-0,31$ & 0,13 & $0,79 *$ & 0,23 & $-0,08$ & $-0,09$ & $-0,04$ & 0,04 & 0,19 \\
\hline Diameter batang $(\mathrm{mm})$ & $-0,56^{*}$ & 0,10 & 0,42 & 0,40 & $-0,13$ & $-0,16$ & $-0,24$ & $-0,11$ & $-0,19$ \\
\hline Lebar kanopi (cm) & $-0,14$ & 0,31 & 0,00 & $0,63 *$ & 0,02 & $-0,35$ & 0,32 & $-0,02$ & $-0,14$ \\
\hline Panjang helai daun $(\mathrm{cm})$ & 0,46 & 0,03 & $0,69 *$ & 0,04 & 0,08 & $-0,07$ & $-0,05$ & $-0,10$ & $-0,27$ \\
\hline Lebar helai daun (cm) & 0,20 & $-0,14$ & $0,76^{*}$ & $-0,01$ & 0,29 & $-0,15$ & 0,29 & $-0,01$ & $-0,12$ \\
\hline Panjang buah (cm) & $0,68^{*}$ & 0,40 & 0,11 & 0,15 & $-0,23$ & 0,12 & $-0,03$ & 0,18 & $-0,17$ \\
\hline Diameterbuah (cm) & $0,94 *$ & $-0,14$ & $-0,05$ & $-0,08$ & $-0,06$ & $-0,04$ & $-0,12$ & $-0,03$ & 0,07 \\
\hline Panjang tangkai buah $(\mathrm{cm})$ & $-0,02$ & $-0,18$ & $0,70 *$ & 0,18 & $-0,13$ & 0,25 & 0,26 & $-0,09$ & 0,31 \\
\hline Tebal daging buah (mm) & $0,68^{*}$ & $-0,45$ & 0,11 & $-0,11$ & $-0,14$ & $-0,19$ & 0,22 & 0,08 & $-0,17$ \\
\hline Jumlah lokul buah & $0,57^{*}$ & $-0,34$ & 0,46 & $-0,10$ & $-0,07$ & $-0,21$ & $-0,12$ & $-0,17$ & $-0,09$ \\
\hline Jumlah buah per tanaman & $-0,42$ & $0,68 *$ & $-0,16$ & 0,47 & $-0,06$ & $-0,02$ & 0,06 & $-0,18$ & $-0,12$ \\
\hline Berat per buah (g) & $0,88^{*}$ & $-0,26$ & 0,18 & 0,12 & $-0,15$ & 0,07 & $-0,08$ & $-0,02$ & 0,09 \\
\hline Jumlah biji per buah & $0,69 *$ & $-0,12$ & 0,00 & 0,00 & $-0,32$ & $-0,18$ & $-0,03$ & $-0,02$ & 0,06 \\
\hline Bobot 1000 biji (g) & 0,25 & $-0,13$ & $-0,10$ & $-0,08$ & $-0,44$ & $0,60 *$ & $-0,13$ & $-0,32$ & $-0,04$ \\
\hline Berat buah per tanaman (g) & 0,12 & $0,68 *$ & $-0,14$ & $0,52 *$ & $-0,21$ & $-0,11$ & $-0,01$ & $-0,23$ & $-0,12$ \\
\hline Warna hipokotil & 0,18 & $0,50 *$ & 0,07 & $-0,06$ & 0,43 & $-0,08$ & 0,04 & $-0,10$ & $0,55^{*}$ \\
\hline Warna buku batang & 0,00 & 0,00 & 0,00 & 0,00 & 0,00 & 0,00 & 0,00 & 0,00 & 0,00 \\
\hline Bentuk batang & 0,00 & 0,00 & 0,00 & 0,00 & 0,00 & 0,00 & 0,00 & 0,00 & 0,00 \\
\hline Bulu batang & 0,00 & 0,00 & 0,00 & 0,00 & 0,00 & 0,00 & 0,00 & 0,00 & 0,00 \\
\hline Tipe pertumbuhan tanaman & $-0,51^{*}$ & 0,13 & 0,12 & $-0,61 *$ & $-0,35$ & $-0,20$ & 0,09 & $-0,31$ & $-0,02$ \\
\hline Tipe percabangan & 0,00 & 0,00 & 0,00 & 0,00 & 0,00 & 0,00 & 0,00 & 0,00 & 0,00 \\
\hline Warna daun & 0,38 & $-0,02$ & $-0,17$ & 0,08 & $-0,23$ & 0,01 & 0,40 & $-0,53^{*}$ & 0,17 \\
\hline Bentuk daun & 0,00 & 0,00 & 0,00 & 0,00 & 0,00 & 0,00 & 0,00 & 0,00 & 0,00 \\
\hline Kerapatan daun & 0,00 & 0,00 & 0,00 & 0,00 & 0,00 & 0,00 & 0,00 & 0,00 & 0,00 \\
\hline Posisi bunga & $-0,50 *$ & $-0,72^{*}$ & $-0,26$ & 0,29 & 0,00 & $-0,13$ & 0,05 & $-0,12$ & 0,10 \\
\hline warna mahkota bunga & 0,00 & 0,00 & 0,00 & 0,00 & 0,00 & 0,00 & 0,00 & 0,00 & 0,00 \\
\hline Warna kepala sari & 0,00 & $-0,05$ & $-0,27$ & 0,05 & $-0,28$ & 0,04 & $0,60 *$ & $0,55^{*}$ & $-0,10$ \\
\hline Warna tangkai sari & 0,00 & 0,00 & 0,00 & 0,00 & 0,00 & 0,00 & 0,00 & 0,00 & 0,00 \\
\hline Tepian kelopak bunga & $-0,51^{*}$ & $-0,18$ & 0,03 & 0,18 & $-0,06$ & $0,51^{*}$ & 0,06 & $-0,07$ & $-0,37$ \\
\hline Posisi buah & $0,50 *$ & $0,72 *$ & 0,26 & $-0,29$ & 0,00 & 0,13 & $-0,05$ & 0,12 & $-0,10$ \\
\hline warna buah sebelum matang & 0,26 & 0,15 & $-0,31$ & $-0,19$ & $0,52 *$ & $-0,03$ & 0,28 & $-0,30$ & $-0,21$ \\
\hline Warna buah matang & $0,50^{*}$ & $0,72 *$ & 0,26 & $-0,29$ & 0,00 & 0,13 & $-0,05$ & 0,12 & $-0,10$ \\
\hline bentuk buah & $0,68^{*}$ & $-0,18$ & $-0,08$ & $0,52 *$ & 0,10 & 0,27 & 0,22 & $-0,10$ & 0,12 \\
\hline bentuk pangkal buah & $0,54^{*}$ & $-0,38$ & $-0,16$ & 0,15 & 0,18 & $-0,38$ & $-0,18$ & $-0,15$ & $-0,31$ \\
\hline bentuk ujung buah & $0,63^{*}$ & $-0,17$ & $-0,11$ & $0,62 *$ & 0,27 & 0,25 & 0,04 & 0,15 & 0,06 \\
\hline leher pada pangkal buah & 0,10 & 0,31 & $-0,05$ & $-0,24$ & $-0,30$ & $-0,28$ & $0,55^{*}$ & $-0,01$ & 0,06 \\
\hline Fruit blossom end ependage & 0,00 & 0,00 & 0,00 & 0,00 & 0,00 & 0,00 & 0,00 & 0,00 & 0,00 \\
\hline Penampang melintang buah & 0,00 & 0,00 & 0,00 & 0,00 & 0,00 & 0,00 & 0,00 & 0,00 & 0,00 \\
\hline Warna biji & 0,00 & 0,00 & 0,00 & 0,00 & 0,00 & 0,00 & 0,00 & 0,00 & 0,00 \\
\hline Eigenvalue & 7,42 & 4,36 & 3,73 & 2,89 & 1,65 & 1,63 & 1,59 & 1,21 & 1,12 \\
\hline Variability (\%) & 23,94 & 14,07 & 12,03 & 9,33 & 5,32 & 5,26 & 5,14 & 3,90 & 3,60 \\
\hline Cumulative \% & 23,94 & 38,01 & 50,04 & 59,37 & 64,69 & 69,95 & 75,09 & 78,99 & 82,59 \\
\hline
\end{tabular}

Keterangan: * berkontribusi nyata terhadap keragaman total

Komponen utama ketujuh (PC7) mempunyai eigenvalue 1,59 memberikan kontribusi terhadap keragaman maksimum sebesar $5,14 \%$. Karakter yang berkontribusi terhadap PC7 ialah warna kepala sari dan leher pada pangkal buah. Komponen utama 
kedelapan (PC8) mempunyai eigenvalue 1,21 memberikan kontribusi terhadap keragaman maksimum sebesar 3,90\%. Karakter yang berkontribusi terhadap PC8 ialah warna kepala sari dan warna daun. Komponen utama kesembilan (PC9) mempunyai eigenvalue 1,12 memberikan kontribusi terhadap keragaman maksimum sebesar $3,60 \%$. Karakter yang berkontribusi terhadap PC9 ialah warna hipokotil. Penelitian yang dilakukan Haydar et al. (2007) menunjukkan bahwa karakter yang berkontribusi terhadap keragaman maksimum pada tanaman kentang adalah karakter-karakter yang yang mempunyai nilai vektor ciri terbesar ialah tinggi tanaman, jumlah daun per tanaman, bobot segar per tanaman, rata-rata bobot umbi per tanaman, bobot umbi per tanaman.

Hasil analisis klaster berdasarkan jarak koefisien korelasi Pearson dan metode aglomerasi unweighted pair-group method average (UPGMA) membagi karakter kuantitatif dan kualitatif dari 39 genotip cabai besar menyebar pada koefisien 91\%-
100\%. Pengelompokan dilakukan pada koefisien kemiripan 97,3\%. Karakter penciri dari masing kelompok diambil dari karakter yang sama terbagi menjadi empat kelompok (Gambar 1). Kelompok pertama terdiri dari 21 genotip yang mengelompok pada koefisien 95,5\% yaitu A4-9(U1-9), B22(U2-7), CB/08-18, CB/08-35, CB/08-36, $\mathrm{CB} / 08-41, \quad \mathrm{CB} / 08-42, \quad \mathrm{CB} / 08-\mathrm{AA3952}$, $\mathrm{CB} / 08-\mathrm{PT} 1146, \quad \mathrm{CB} / 09-\mathrm{BW} 22, \quad \mathrm{CB} / 09-$ BW32, CB/09-BW42, CB/09-BW52, CB/1014-R7/8, CB/10-21-T1, CB/10-22-T2, $\mathrm{CB} / 10-38-\mathrm{TJ} 2, \quad \mathrm{CB} / 10-40 \mathrm{BT} 2, \quad \mathrm{CB} / 10-$ UK154, G10(12), G7(5). Kelompok kedua terdiri dari 4 genotip yang mengelompok pada koefisien $96,6 \%$, yaitu B6-38(U2-1), B6-38(U2-2), CB/08-28, CB/10-17-U. Kelompok ketiga terdiri dari 12 genotip yang mengelompok pada koefisien 96,6\%,yaitu B6-38(U2-2B), CB/08-39-TS, $\mathrm{CB} / 08-48, \quad \mathrm{CB} / 08-5, \mathrm{CB} / 08-6, \mathrm{CB} / 08-$ BTR32, CB/08-PT1456, CB/09-BW12, $\mathrm{CB} / 10-09-\mathrm{RO}, \quad \mathrm{CB} / 10-12-\mathrm{R}, \quad \mathrm{CB} / 10-$ CYM2151, G11(7).

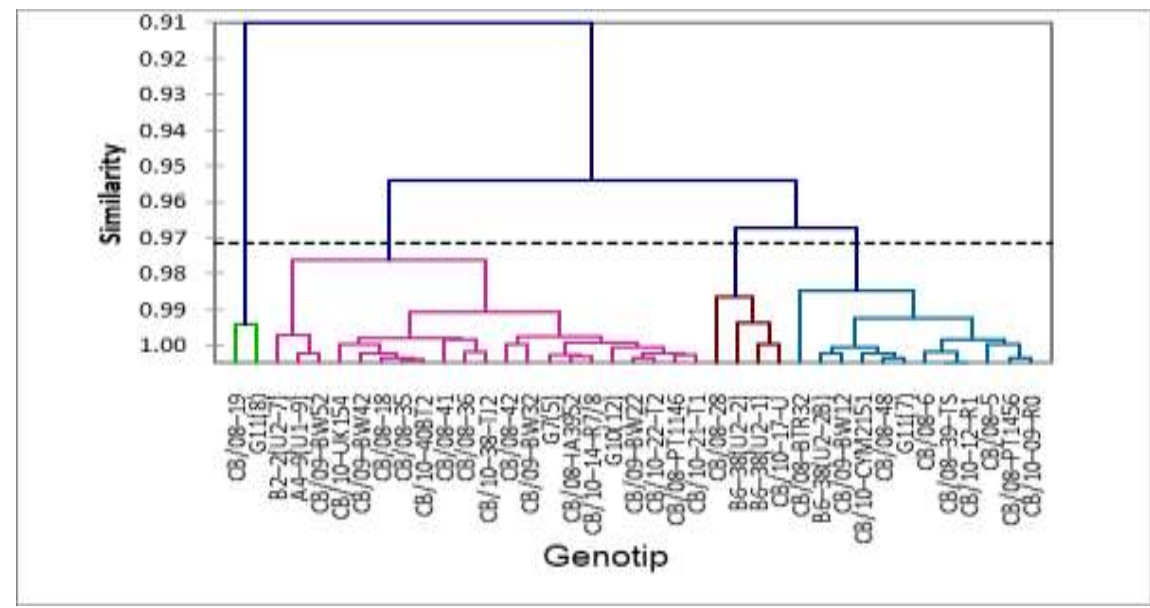

Gambar 1. Dendogram 39 genotip cabai berdasarkan 42 karakter agronomi

Kelompok keempat terdiri dari 2 genotip yang mengelompok pada koefisien 91\%, yaitu CB/08-19, G11(8). Nilai koefisien kemiripan menunjukkan kesamaan individu dalam suatu populasi, semakin tinggi nilai koefisien kemiripan antar individu, maka 
semakin dekat jarak genetik antar individu tersebut (Lebeda and Jendrulek, 1987; Sunil and Ahmad, 1998; Deka et al., 2016). Pengelompokkan genetik pada cabai telah dilakukan oleh Yulianah et al. (2016) untuk menyeleksi genotip-genotip potensial.

Jarak genetik berdasarkan karakter agronomi kualitatif dan karakter agronomi kuantitatif menunjukkan keeratan nyata positif yang ditunjukkan dengan nilai koefisien korelasi $(r=0,173 ; P<0,0001)$ berdasarkan uji Mantel (Gambar 2). Nilai tersebut menunjukkan bahwa terdapat korelasi yang positif antara jarak genetik menggunakan 24 karakter agronomi kualitatif dan 18 karakter agronomi kuantitatif. Hal ini berarti bahwa karakter kualitatif atau kuantitatif dapat digunakan dalam menduga jarak dan perbedaan genetik pada cabai besar. Menurut Mattjik dan Sumertajaya (2006), koefisien korelasi adalah koefisien yang menggambarkan tingkat keeratan hubungan liniear antara dua peubah atau lebih. Besaran dari koefisien korelasi tidak menggambarkan hubungan sebab akibat antara dua peubah atau lebih tapi hanya menggambarkan keterkaitan linier antar peubah. Koefisien korelasi ( $r$ ) nilainya berkisar antara -1 dan 1 $(-1 \leq r \leq 1)$. Nilai $r$ yang semakin mendekati 1 atau 1 menunjukkan semakin erat hubungan linier antara kedua peubah tersebut sedangkan nilai $r$ yang mendekati nol menggambarkan hubungan kedua peubah tersebut tidak linier.

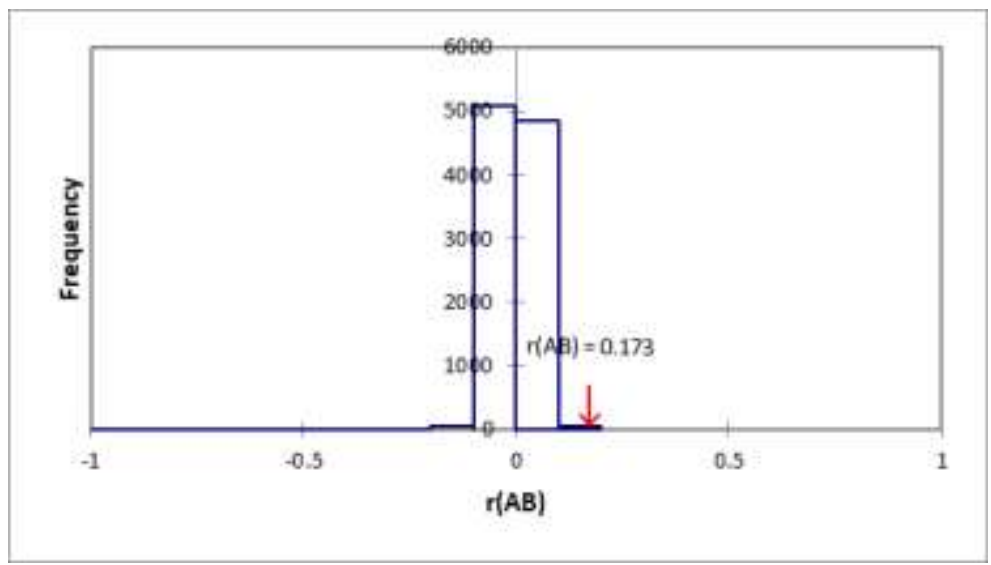

Gambar 2. Keeratan jarak genetik 39 genotip cabai berdasarkan 24 karakter agronomi kualitatif dan 18 karakter agronomi kuantitatif berdasarkan uji Mantel

Analisis indek keanekaragaman menurut indek Shannon $\left(H^{\prime}\right)$ yang didasarkan kepada pengelompokkan berdasarkan jarak genetik pada Gambar 1 menunjukkan nilai 1,08 . Nilai tersebut termasuk dalam kategori yang sedang. Menurut Lind (1979) dikutip Amin (2008), indeks keanekaragaman yang mendekati nol cenderung menunjukkan komunitas atau kelompok yang tidak stabil sedangkan jika mendekati satu menunjukkan komunitas dalam keadaan stabil, jumlah individu antar spesies yang sama. Menurut indeks Simpson (D), nilai dominansi 0,39 memperlihatkan tidak adanya dominansi. Nilai dominansi dari hasil analisis menunjukkan bahwa tidak terdapat dominansi pada kelompok galur-galur cabai besar yang ditunjukkan dengan kategori $0<$ $\mathrm{D} \leq 0,5$ (Magurran, 2004). Cabai besar dari 39 genotip tidak mengalami dominansi pada karakter kualitatif dan kuantitatif sehingga 
tidak terdapat genotip yang secara ekstrim mendominasi genotip lainnya. Menurut Basmi (2000) apabila nilai dominansi mendekati nilai 1 berarti di dalam komunitas terdapat genotip yang mendominasi genotip lainnya, sebaliknya apabila mendekati nilai 0 berarti di dalam struktur komunitas tidak terdapat genotip yang secara ekstrim mendominasi genotip lainnya.

Proporsi distribusi dari galur-galur cabai besar berdasarkan pengelompokkan jarak genetik yang terbagi menjadi 4 kelompok. Kelompok A yang memilik proporsi kelimpahan 54\%, yaitu A4-9(U19), $\mathrm{B} 2-2(\mathrm{U} 2-7), \mathrm{CB} / 08-18, \mathrm{CB} / 08-35$, $\mathrm{CB} / 08-36, \mathrm{CB} / 08-41$, $\mathrm{CB} / 08-42, \mathrm{CB} / 08-$ IA3952, CB/08-PT1146, CB/09-BW22,
CB/09-BW32, CB/09-BW42, CB/09-BW52, $\mathrm{CB} / 10-14-\mathrm{R} 7 / 8, \mathrm{CB} / 10-21-\mathrm{T} 1, \mathrm{CB} / 10-22-$ T2, CB/10-38-TJ2, CB/10-40BT2, CB/10UK154, G10(12), G7(5). Kelompok B yang memiliki proporsi distribusi $10 \%$, yaitu $B 6-$ 38(U2-1), B6-38(U2-2), CB/08-28,CB/10$17-U$. Kelompok $C$ yang memiliki proporsi distribusi $31 \%$, yaitu $\mathrm{B} 6-38(\mathrm{U} 2-2 \mathrm{~B}), \mathrm{CB} / 08-$ 39-TS, CB/08-48, CB/08-5, CB/08-6, $\mathrm{CB} / 08-\mathrm{BTR} 32, \quad \mathrm{CB} / 08-\mathrm{PT} 1456, \quad \mathrm{CB} / 09-$ BW12, CB/10-09-R0, CB/10-12-R1, CB/10CYM2151, G11(7). Kelompok $D$ yang memiliki proporsi distribusi 5\%, yaitu CB/08-19, G11(8) (Gambar 3). Berdasarkan persentase kelimpahan Goepel (2014), kelompok A mempunyai kelimpahan yang tinggi dan kelompok $D$ mempunyai kelimpahan yang rendah.

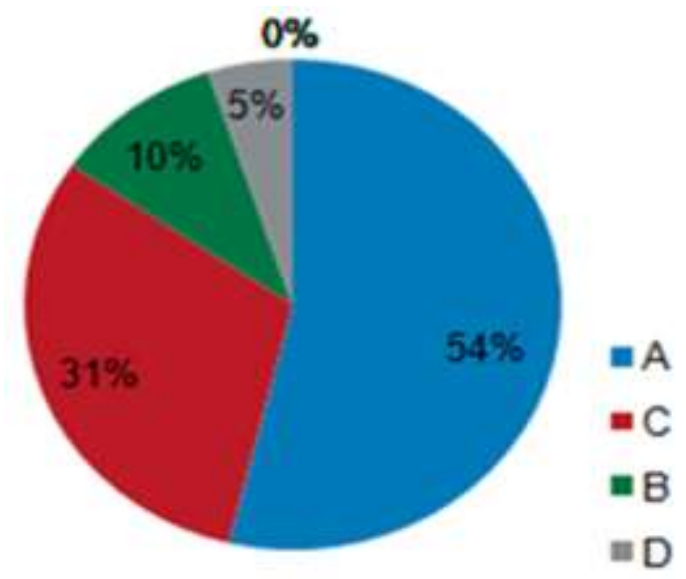

Gambar 3. Diagram proporsi kelimpahan 39 genotip cabai besar

\section{SIMPULAN}

1. Hasil analisis komponen utama karakter agronomi yang memiliki eigenvalue $>1$ dengan nilai keragaman kumulatif 82,59\% dan factor loading > 0,5 terbagi menjadi 9 komponen utama. Karakterkarakter yang berkontribusi pada keragaman maksimum ialah tinggi tanaman, diameter batang, jumlah lokul buah, posisi bunga, tepian kelopak bunga, bentuk pangkal buah, panjang buah, diameter buah, tebal daging buah, berat per buah, jumlah biji per buah, bentuk buah, warna buah matang, posisi buah, tipe pertumbuhan tanaman, bentuk ujung buah, warna hipokotil, umur berbunga, jumlah buah per tanaman, berat buah per tanaman, posisi bunga, panjang batang utama, 
panjang helai daun, lebar helai daun, panjang tangkai buah, lebar kanopi, bentuk buah, warna buah sebelum matang, tepian kelopak bunga, bobot 1.000 biji, warna kepala sari, leher pada pangkal buah, dan warna daun.

2. Terdapat empat kelompok genetik cabai besar berdasarkan karakter morfoagronomi dengan koefisien kemiripan 91\%-100\%.

3. Tingkat keanekaragaman kelompok galur cabai dengan kelimpahan tertinggi terdapat pada kelompok A (54\%) dan terendah pada kelompok D (5\%).

4. Informasi mengenai keragaman karakter dan keanekaragaman galur dapat digunakan sebagai bahan pertimbangan pemilihan tetua cabai untuk perbaikan genetik di dalam pemuliaan tanaman.

\section{UCAPAN TERIMAKASIH}

Penelitian ini didanai oleh BOPTN 2017 Fakultas Pertanian Universitas Brawijaya dengan ketua peneliti Dr. Budi Waluyo SP., MP.

\section{DAFTAR PUSTAKA}

Amin M., dan Utojo. 2008. Komposisi dankeragaman jenis plankton di perairan Teluk Kupang Provinsi Nusa Tenggara Timur. Torani. 18 (2) : 129 135.

Basmi, H. J. 2000. Planktonologi: Plankton sebagai Indikator Kualitas Perairan.Bogor: Fakultas Perikanan dan Ilmu Kelautan, Institut Pertanian Bogor

Deka, S.D., M. Dadlani, and R. Sharma. 2016. Diversity study in capsicum using numerical taxonomy. Sabrao J. Breed. Genet. 48(3): 277-284.

Direktorat Jenderal Hortikultura. 2015. Statistik Produksi Hortikultura 2014. Kementerian Pertanian, Jakarta

Geleta, L.F., M.T. Labuschagne, and C.D. Viljoen. 2004. Relationship between heterosis and genetic distance based on morphological traits and AFLP markers in pepper. Plant Breed. 123(5): 467-473.

Goepel, K. D. 2013. Implementing the analytic hierarchy process as a standard method for multi-criteria decision making in corporate enterprises - a new ahp excel template with multiple inputs. Proceedings of the International Symposium on the Analytic Hierarchy Process 2013. pp.1-10.

Haydar A., M. B. Ahmed., M. M.Hanan., M. A. Rasvy., M. A. Mandal., M. Salahin., R. Karin., and M. Hossain. 2007. Analysis of genetic diversity in some potato varieties grown in Bangladesh. J. Sci. Res. 2(3-4): 143-145.

Hughes, A.R., B.D. Inouye, M.T.J. Johnson, N. Underwood, and M. Vellend. 2008. Ecological consequences of genetic diversity. Ecol. Lett. 11(6): 609-623.

IPGRI. 1995. Descriptor for Capsicum. Taiwan: International Plant Genetic Resources Institute. pp.47.

Julisaniah, N. I., L. Sulistyowati., dan A. N. Sugih. 2008. Analisis kekerabatan mentimun (Cucumis sativus L.) menggunakan metode RAPD-PCR dan isoenzim. Biokeanekaragaman. 9(2): 99-102.

Krishnamurthy, S., A.M. Rao, K.M. Reddy, S. Ramesh, S. Hittalmani, and R.M. Gopinath. 2012. Relationship 
between morphological and amplified fragment length polymorphism (AFLP) marker based genetic distance with heterosis in hot pepper (Capsicum annuum L.). African J. Biotechnol. 11(74): 13863-13872.

Lahbib, K., F. Bnejdi, and M. El Gazzah. 2013. Selection of pepper parent from a collection of Capsicum annuum landraces based on genetic diversity. J. Plant Breed. Crop Sci. 5(5): 68-72.

Lebeda, A., and T. Jendrulek. 1987. Cluster analysis as a method for evaluation of genetic similarity in specific host parasite interaction (Lactuca sativa Bremia lactucae ). Theor. Appl. Genet. 75: 194-199.

Lowe, A., S. Harris, and P. Ashton. 2006. Ecological Genetics (Design, Analysis and Application). Blackwell publishing: Singapore.

Magurran, A. E. 2004. Meausuring Biological Diversity. UK : Blackwell Science Ltd. p.256.

Mattjik, A.A. dan Sumertajaya. 2006. Perancangan Percobaan Jilid 1 Edisi ke- 2. Bogor: IPB Press. pp. 64.

Maurer, B., and B. McGill. 2011. Measurement of species diversity. Biol. Divers. Front. Meas.: 55-65.

Moses, M., and P. Umaharan. 2012. Genetic structure and phylogenetic relationships of Capsicum chinense. J. Am. Hortic. Sci. 137(4): 250-262.

Setiawati, T., W. Chandaria dan A. Kurniawan. 2010. Karakterisasi kerabat liar ubi jalar asal citatah jawa barat sebagai sumber genetik potensial untuk merakit hibrida ubi jalar tipe baru berkualitas tinggi.
Prosiding Seminar Nasional Hortikultura, Indonesia. pp.603-608.

Shiva, K., P. Gobinath, T. Zachariah, and N. Leela. 2014. Variability in quality attributes of paprika and paprika alike chillies (Capsicum annuum L.). J. Spices Aromat. Crop. 23(1): 17-25.

Sitaresmi, T., S. Sujiprihati, and M. Syukur. 2010. Combining ability of several introduced and local chilli pepper (Capsicum annuum L.) genotypes and heterosis of the offsprings. J. Agron. Indones. 38(3): 212-217.

Sriyadi, B. 2015. Penilaian hubungan genetik klon teh berdasarkan komponen senyawa kimia utama dan potensi hasil. J. Penelitian Teh dan Kina. 18(1): 1-10

Sunil, K., and R. Ahmad. 1998. Diversity and horticultural grouping in Capsicum spp. J. Spices Aromat. Crop. 7(1): 2733.

Syukur, M., S. Sujiprihati, R. Yunianti, dan A. Kusumah. 2011. Pendugaan ragam genetik dan hasil heritabilitas karakter komponen hasil beberapa genotipe cabai. J. Agrivigor Indones. 10(2): 148-156.

Woolford, S. 2015. (Factor) Analyze This PCA or EFA. PSTAT, CQE. Genetic Counseling Training Program, July 31, 2015. National Human Genome Research Institute, The Johns Hopkins University.

Yulianah, I., Respatijarti, B. Waluyo, dan G. Lasmono. 2016. Keragaman karakter dan pengelompokkan genotip potensial cabai berdasarkan karakter agronomi. pp. 188-190. Dalam Ariyanto, D.P., Yuniastuti, E., Hadiwiyono (eds.), Prosiding Seminar Nasional : Peran Agroteknologi/ Agroekoteknologi dalam 
Mewujudkan Ketahanan Pangan dan Energi. Program Studi Agroteknologi Fakultas Pertanian Universitas Sebelas Maret Surakarta, Surakarta.

Zhigila, D.A., A.A. AbdulRahaman, O.S. Kolawole, and F.A. Oladele. 2014. Fruit morphology as taxonomic features in five varieties of Capsicum annuum L. Solanaceae. J. Bot.: 1-6. 